\title{
Mental Health, Physical Health and Other Individual Risk Factors for Elder Maltreatment: Findings from the National Study
}

\author{
Marijana Markovik $^{1^{\star}}$, Dimitrinka Jordanova Peshevska ${ }^{2}$, Eleonora Serafimovska ${ }^{1}$, Dinesh Sethi $^{3}$ \\ ${ }^{1}$ Institute for Sociological, Political and Juridical Research, Ss Cyril and Methodius University of Skopje, Republic of \\ Macedonia; ${ }^{2}$ World Health Organization, Country Office Skopje, Republic of Macedonia; ${ }^{3}$ World Health Organization, \\ Regional Office for Europe, Copenhagen, Denmark
}

\begin{abstract}
Citation: Markovik M, Jordanova Peshevska D, Serafimovska E, Sethi D. Mental Health, Physical Health and Other Individual Risk Factors for Elder Maltreatment: Findings from the National Study. OA Maced J Med Sci. 2014 the National Study. OA Maced J Med Sci. 2014
Jun $\begin{array}{ll}\text { Jun } & 15 ; \\ \text { http://dx.doi.org/10.3889/oamjms.2014.062 }\end{array}$

Key words: risk factors on individual level; elderly maltreatment; private households.

"Correspondence: Marijana Markovik, PhD. Institute for Sociological, Political and Juridical Research, University "St. Kiril and Metodij", 1000 Skopje, PO Box 435, "Bulevar Partizansk odredi bb", Republic of Macedonia. Tel.: +389 75291 672; Fax: +389 23061 282. E-mail marijana@isppi.ukim.edu.mk,

vaogma@yahoo.com

Received: 25-Feb-2014; Revised: 22-Apr2014; Accepted: 23-Apr-2014; Online first: 16-May-2014

Copyright: () 2014 Markovik et al. This is an open access article distributed under the terms of the Creative Commons Attribution License, which permits unrestricted use, distribution, and reproduction in any medium, provided the original author and source are credited.

Competing Interests: The authors have declared that no competing interests exist.
\end{abstract}

\begin{abstract}
OBJECTIVES: The first Macedonian National Prevalence study of elder maltreatment in private settings was conducted in 2011 and 2012. This article provides an overview of the risk factors on individual level regarding the ecological model of human development.

METHOD: The study involved 960 respondents who provided answers to a face-to-face survey questionnaire and a Geriatric Depression Scale. The Mini-Mental State Examination test was used as a pre selection criterion. The achieved sample was weighted to be representative on the Macedonian population aged 65 and over.

RESULTS: Being women, being married, with elementary school education, suffering from certain chronic diseases, sensory impairment, are potential risk factors on individual level for elderly Maltreatment.

CONCLUSION: The findings support the previous quantitative data obtained in other countries, as well as the concept of ecological framework.
\end{abstract}

\section{Introduction}

Elderly maltreatment has only recently been recognized as a global problem [1]. This problem was first identified in developed countries where most of existing research has been conducted [2]. However, case studies and reports from some developing countries have pointed out that it is a universal phenomenon [3].

In the country there has been lack of a systematic scientific approach to elder maltreatment until recently. The only data on elder maltreatment are based on reports from agencies working in the field of domestic violence [4]. It has been observed that $4 \%$ of reported cases of intimate partner violence are among elderly people. The National SOS line for victims of domestic violence in 2010 identified 495 calls from victims aged over 60 , which represents $17 \%$ of the total number of calls, and another 24-hour SOS line identified that $35 \%$ of calls were made by people aged over 65, reporting abuse by their children and grandchildren [5].

The data used in this article is an integral part of the data collected for more comprehensive project "A Community survey in Macedonia of the prevalence of elderly abuse". The study has been conducted during the period from December 2011 to February 2012. Implementation of the study was enabled with technical and financial support by the World Health Organization in collaboration with the Institute of Sociological, Political and Juridical Research in Skopje. 


\section{Definition of elderly Maltreatment}

According to the World Health Organization (WHO) [1], maltreatment can have various forms of physical, psychological, emotional, sexual, and financial abuse. It can also occur as a result of intentional or unintentional neglect. Also, the term maltreatment was used to refer to both neglect and abuse [6]; abuse was used to refer to psychological, physical, financial and sexual abuse.

One commonly used definition of maltreatment is the one adopted by the WHO and the International Network for Prevention of Elder Abuse (INPEA): Elder Maltreatment is a single or repeated act, or lack of appropriate action, occurring within any relationship where there is an expectation of trust, which causes harm or distress to an older person [1, 2].

In research and policy literature [2], the following types of elder maltreatment have been identified: physical abuse includes violent actions which can cause physical pain or injuries; psychological/emotional abuse refers to actions which can cause mental pain or distress; financial/material abuse refers to all actions or illegal use of an older person's property, sexual abuse is an intention to control the partner or another person sexually and is only one sided. Neglect can be passive or active. Passive neglect refers to unintentional absence of providing necessary care to an older person. Active neglect refers to intentional absence of providing basic necessary elements of care.

\section{Ecological model of understanding elder maltreatment}

The ecological framework employs a multidimensional view of interpersonal violence. It examines violence as an outcome of the interaction between individual, relational, community-level and societal factors. The ecological model explores the interactions between the individual and the contextual factors. It considers violence as a result of the complex interplay between the person's individual characteristics, close interpersonal relationships, characteristics of the community in which the person lives or works and societal factors such as policies and social norms. The ecological model allows elderly abuse to be linked to broader social issues [7].

\section{Risk Factors}

Risk factors of violence, in particular, are variables which make a person vulnerable to violent behaviors and attitudes [8]. The risk factors following the ecological conceptual framework are grouped into four categories [2]: individual, relationship and community and societal level.

This paper has been focused on investigating the individual risk factors according to the ecological model: socio-economic factors (income personal, employment, and educational level); sociodemographic determinants (age, marital status); health status (physical health status, mental health status, depression, life style factors - smoking and alcohol use, subjective perceptions of sensory system functioning).

\section{Method}

The study was a community based household survey at national level, involved administering a questionnaire. The ethics committee (professors from the Law and Medical Faculty of the University "Ss Cyril and Methodius") granted ethical approval to the study. The general objective was to explore the phenomenon of elder maltreatment (of people aged 65 and over). The principal goal of this study was to explore the risk factors of elder maltreatment on individual level.

\section{Measures}

The study used a Questionnaire and the Geriatric Depression Scale. The demographic data collected were sex, age, ethnical background, educational level, marital status, personal income and region.

\section{Questionnaire}

The Questionnaire already developed and applied in the research was used for this national prevalence research on elder maltreatment. The questionnaire used in the Macedonian survey followed the design of the questionnaire applied in the ABUEL survey -Abuse of Elderly in Europe, a multinational prevalence survey, conducted in Germany, Greece, Italy, Lithuania, Portugal, Spain, Sweden, [9]. In addition, some questions which were more user friendly were accepted from the AVOW questionnaire - Prevalence study of abuse and violence against older women, a multicultural survey conducted in Austria, Belgium, Finland, Lithuania and Portugal, [10]. The final version of the questionnaire was available both in Macedonian and Albanian language. A qualitative analysis of the Final Questionnaire Form has been undertaken by a Focus group of experts and the Scientific Committee of the study. As a result of the comments provided by both groups of experts, the final version of the questionnaire has been completed. The final structure of the questionnaire used in the Macedonian study contains questions addressing: socio-demographic factors (14 questions); life styles factors (smoking, alcohol use, diet-10 questions); selfreported physical and mental health; depression (measured with the Geriatric Depression Scale-15 questions); hearing and vision (10 questions) 
exposure to abuse/neglect (psychological abuse, physical abuse, physical injury; financial abuse; sexual abuse and neglect), questions about perpetrators (gender, age, kinship) and questions about the reactions following the abuse (32 questions). Total number of questions in Questioner was 81 .

The length of the face to face interviews was 60 minutes approximately and was conducted in either Macedonian or Albanian, depending on the participant's preferences. The length of the time, in some cases was more or less than 60 minutes, this depended of circumstances. To increase the participant's privacy and protection, respondents were asked if they have a place in their own home where they could talk privately.

Table 1: Characteristics of the sample.

\begin{tabular}{|c|c|}
\hline Gender & Total\% \\
\hline Male & 44.7 \\
\hline Female & 55.3 \\
\hline Age & Total \% \\
\hline $65-69$ & 32.0 \\
\hline $70-74$ & 28.9 \\
\hline $75-79$ & 22.1 \\
\hline $80-84$ & 12.7 \\
\hline Over 85 & 4.3 \\
\hline Ethnicity & Total \% \\
\hline Macedonian & 76.4 \\
\hline Albanian & 16.0 \\
\hline Roma & 1.9 \\
\hline Serb & 1.1 \\
\hline Vlach & 0.5 \\
\hline Turkish & 2.1 \\
\hline Bosnian & 1.0 \\
\hline Other & 1.0 \\
\hline Level of education & Total \% \\
\hline No education & 10.4 \\
\hline Did not complete primary school & 25.8 \\
\hline Primary school education & 26.8 \\
\hline Secondary education & 25.2 \\
\hline University/other higher education & 11.2 \\
\hline Specialist, MA, PhD & 0.6 \\
\hline Marital status & Total \% \\
\hline Single (never married) & 3.6 \\
\hline Married/civil partnership) & 56.7 \\
\hline Divorced & 2.0 \\
\hline Widowed & 37.7 \\
\hline Occupational status & Total \% \\
\hline Fully retired & 87.5 \\
\hline Full-time employed & 0.6 \\
\hline Part-time employed & 0.4 \\
\hline Unemployed & 11.5 \\
\hline Personal income in euro & Total \% \\
\hline Up to 80 & 7.4 \\
\hline $81-146$ & 40.8 \\
\hline $147-226$ & 27.5 \\
\hline $227-307$ & 10.8 \\
\hline $308-388$ & 3.4 \\
\hline $389-467$ & 1.3 \\
\hline$<468$ & 0.9 \\
\hline No income & 7.9 \\
\hline Region & Total\% \\
\hline Pelagonija & 13.5 \\
\hline Vardar & 8.0 \\
\hline North-eastern & 7.4 \\
\hline South-western & 9.8 \\
\hline Skopje & 30.2 \\
\hline South-eastern & 9.1 \\
\hline Polog & 10.8 \\
\hline Eastern & 11.2 \\
\hline
\end{tabular}

Depression was measured by use of the Geriatric Depression Scale. This scale was developed as a basic screening instrument for depression in old age [11]. The Serbian version of this Geriatric scale (adapted in Macedonian language) which is a short version containing 15 items was used [12]. The 15 items version is most widely used through self-report or informant report and it takes 5-10 minutes to complete [11].

\section{Sample}

Sampling was carried out by: quota and strata. Sample size was 960 , which represents $0.4 \%$ of the total number of people over the age of 65 . This sample includes the appropriate ratio of men and women and was constructed according to the following criteria: gender, ethnic background, municipality, city/village and region. The quota of respondents depended on the population distribution [13].

\section{Exclusion criteria}

The Exclusion criterion developed included people lacking mental capacity (such as dementia). To help assess whether the potential participants were able or unable to fully participate in the study, the Mini-Mental State Examination (MMSE) test was used [14]. The MMSE is a widely used screening tool for evaluation of cognitive impairment. It briefly measures the orientation in time and space, immediate recall, short-term verbal memory, calculation, language and construction ability [14-16]. Respondents with low scores (cutoff score is 24) were not included in the sample (only 23 respondents were excluded from the research); all others were invited to complete the survey (each respondent signed a consent form) and confidentiality was guaranteed. Total number of potential respondents was 983,23 of them were excluded according to the results obtained on MMSE test, so final number of respondents who completed questioner was 960 .

\section{Data analysis}

Data input and data analysis were conducted in the SPSS (19) program. The following statistical methods have been used: Cronbah Alpha, Factor analysis, Chi-square analysis, statistically significant difference between the percentage and binary logistic regression. Statistical significance was set at $p<0.05$ for all analyses.

Factor analysis and Cronbah alpha has been used to check the reliability of the Geriatric Depression Scale (GDS). Chi-square analysis and Statistical significant difference between the percentages was used to examine categorical variables: "gender", "education", "somatic illness" and "sensory functions" (vision, hearing). Following the identification of the variables considered as relevant to elderly abuse, further statistical analysis has been conducted. In order to identify the variables of influence on elderly abuse and neglect the binary logistic regression was applied. 


\section{Results}

The findings from the first Macedonian National Prevalence Study showed that $32 \%$ of all respondents experienced some type of maltreatment. The most common type was psychological abuse $(25.7 \%)$, followed by financial abuse $(12.0 \%)$, neglect $(6.5 \%)$, physical abuse $(5.7 \%)$, physical injury $(3.1 \%)$ and sexual abuse was the least type of maltreatment reported only by females $(0.2 \%)$.

\begin{tabular}{lcc}
\multicolumn{3}{c}{ Table 2. Diseases in frequencies and percentages $\mathbf{( N = 9 6 0 ) . ~}$} \\
\hline Diseases & Frequencies & Percentage \\
\hline Allergy & 152 & 15.8 \\
Asthma & 92 & 9.5 \\
Diabetes & 228 & 23.7 \\
Cardiovascular diseases & 499 & 52.0 \\
Liver diseases & 44 & 4.6 \\
Stomach diseases & 154 & 16.1 \\
Cancer & 28 & 3.0 \\
Lung diseases & 100 & 10.4 \\
Brain diseases & 91 & 9.5 \\
Rheumatism & 522 & 54.4 \\
Mental health diseases & 144 & 15.0 \\
\hline
\end{tabular}

Table 2 shows distribution of diseased in frequencies and percentages. Binary logistic regression was conducted in order to compare the probability "have been abused/neglected" dependent on the level or category of the independent variables on individual, relationship level and society/community level. The binary logistic regression for the selected independent variables shows several significant results.

Table 3: Likelihood of Elder Abuse/neglect on Individual.

\begin{tabular}{|c|c|c|}
\hline & & $\begin{array}{l}\text { Abused/neglected versus not } \\
\text { abused/not neglected } \\
\text { Odds ratio }\end{array}$ \\
\hline \multicolumn{3}{|l|}{ Individual level } \\
\hline & No education & ns \\
\hline & Incomplete education & ns \\
\hline \multirow{3}{*}{ Education } & Elementary & $1.559^{\star \star}$ \\
\hline & Secondary & ns \\
\hline & High & ns \\
\hline \multirow[t]{5}{*}{ Age } & $65-69$ & ns \\
\hline & $70-74$ & ns \\
\hline & $75-79$ & ns \\
\hline & $80-84$ & ns \\
\hline & $<85$ & ns \\
\hline Ethnicity & Macedonian/Albanian & ns \\
\hline Gender & Female & $1.372^{*}$ \\
\hline \multirow[t]{6}{*}{ Marital status } & Married (civil partnership) & $1.055^{*}$ \\
\hline & Allergy & ns \\
\hline & Asthma & $\mathrm{ns}$ \\
\hline & Diabetes & (ns) \\
\hline & Cardio- vascular & $\mathrm{ns}$ \\
\hline & Liver & ns \\
\hline \multirow{5}{*}{$\begin{array}{l}\text { Physical health } \\
\text { (self-reported) }\end{array}$} & Stomach & $2.056^{* *}$ \\
\hline & Lung & ns \\
\hline & Cancer & $0.229^{*}$ \\
\hline & Cerebral-vascular diseases & ns \\
\hline & Rheumatism & ns \\
\hline \multirow{2}{*}{ Mental health } & $\begin{array}{l}\text { Mental health problems (self } \\
\text { reported) }\end{array}$ & $1.877^{\star *}$ \\
\hline & Depression (low level) & $1.726^{\star \star}$ \\
\hline \multirow{4}{*}{$\begin{array}{l}\text { Sensory } \\
\text { functioning } \\
\text { (hearing) }\end{array}$} & Very week & ns \\
\hline & Week & ns \\
\hline & Nether good nether bad & $1.920^{\star *}$ \\
\hline & Good & $\mathrm{ns}$ \\
\hline \multirow{4}{*}{$\begin{array}{l}\text { Sensory } \\
\text { functioning } \\
\text { (vision) }\end{array}$} & Very week & ns \\
\hline & Week & $1.671^{*}$ \\
\hline & Nether good nor bad & $1.391^{*}$ \\
\hline & Good & ns \\
\hline \multirow{8}{*}{$\begin{array}{l}\text { Personal } \\
\text { income in MKD }\end{array}$} & Till 5000.00 & ns \\
\hline & $5001.00-9000.00$ & ns \\
\hline & $9001.00-14000.00$ & ns \\
\hline & $14001.00-19000.00$ & ns \\
\hline & $19001.00-24000.00$ & ns \\
\hline & $24001.00-29000.00$ & ns \\
\hline & $<30000.00$ & ns \\
\hline & No income & ns \\
\hline
\end{tabular}

Older people with elementary education showed a higher estimated probability of being abused compared to those with higher education or no education. Women had higher estimated probability of being abused compared to men. Married had a higher probability of being abused compared to those who were not married (widowed, separated, single).

Participants were asked if they have some of following diseases: allergy, asthma, diabetes, cardiovascular diseases, liver diseases, stomach diseases, lung disease, cancer, rheumatism, and cerebral-vascular diseases, or some mental health problems. Respondents who reported some chronic physical diseases (stomach diseases, cancer) had a higher likelihood of being abused/neglected. Furthermore, respondents who reported poor mental health had a higher likelihood of being abused compared to those indicating good mental health. Respondents having a score of 16 (cutoff score) and above on the (GDS) had a lower likelihood of being abused/neglected compared to those indicating lower scores on GDS. Reliability analysis allows study of the items which are the property of the measurement scale. In this case Cronbach's Alpha has been used as a model of internal consistency, based on the average inter-item correlation. According to the data obtained with first consistence analysis, GDS was reduced on 9 items. Cronbach's Alpha for reduced form of GDS scale is 0.84 , which refers to the high consistency of the scale.

The minimum score on the reduced scale can be 9 and the maximum score can be 18 points. Each question can take 1 or 2 points. Higher scores (above 16) indicate severe depression.

The maximum score on the original short form of this scale can be 15 and the lowest can be 0 . The highest intensity of depression can be assumed if the score is above 10 .

Namely, by increasing the level of depression there is a decrease of the abuse/neglect level among respondents $(r=-0.29, p<0.01)$.

In this survey the condition of the two senses has been explored: vision and hearing, taking into consideration that they are the most important in old age. Respondents who reported that their hearing and vision are "neither good nor bad" had a higher likelihood of being abused/neglected compared to those who are of good sensory function (hearing and vision). Few independent variables were recognized as relevant risk factors for elderly abuse on relationships level: cohabitant status (those living with closer relatives had a higher likelihood of being abused/neglected compared to those living with a partner, a partner and child, with a child only and wider family, or living alone.

Binary logistic regression was conducted to compare the probability of exposure (or absence of) to 
different types of maltreatment according to healthrisk behavior, physical and mental health as independent variables at individual level Data are presented in Table 3.

With regard to psychological abuse, it is 1.9 times more likely in older people with asthma, 1.4 times more likely for cardiovascular diseases, 2.5 times more likely for liver disease, 1.8 times more likely for stomach disease, 1.4 times more likely for rheumatism, and 1.6 times more likely for mental health problems.

Table 4: Likelihood of all types of elder abuse/neglect on physical and mental health and health risk behavior).

\begin{tabular}{|c|c|c|c|c|c|c|}
\hline \multirow[b]{2}{*}{ Diseases } & \multicolumn{6}{|c|}{ Odds ratio } \\
\hline & $\begin{array}{l}\text { Psychological } \\
\text { abuse }\end{array}$ & $\begin{array}{c}\text { Physical } \\
\text { abuse }\end{array}$ & $\begin{array}{l}\begin{array}{l}\text { Physical } \\
\text { injuries }\end{array} \\
\end{array}$ & $\begin{array}{c}\begin{array}{c}\text { Financial } \\
\text { abuse }\end{array} \\
\end{array}$ & $\begin{array}{l}\text { Sexual } \\
\text { abuse }\end{array}$ & Neglect \\
\hline \multicolumn{7}{|c|}{ Physical health } \\
\hline Allergy & Ns & ns & ns & ns & $5.934^{\star \star}$ & ns \\
\hline Asthma & $1.875^{*}$ & $2.502^{*}$ & ns & ns & ns & $2.857^{* *}$ \\
\hline Diabetes & Ns & $\mathrm{ns}$ & ns & ns & ns & $1.762^{*}$ \\
\hline Cardio- & $1.370^{*}$ & ns & ns & ns & ns & ns \\
\hline $\begin{array}{l}\text { Liver } \\
\text { Liver }\end{array}$ & $2.466^{* \star}$ & ns & ns & ns & ns & ns \\
\hline Stomach & $1.790^{* *}$ & ns & ns & $1.694^{*}$ & ns & ns \\
\hline Lung & $0.550^{*}$ & ns & ns & ns & ns & ns \\
\hline Cancer & ns & ns & ns & ns & $\mathrm{ns}$ & ns \\
\hline $\begin{array}{l}\text { Cerebral- } \\
\text { vascular } \\
\text { diseases }\end{array}$ & ns & ns & ns & ns & ns & ns \\
\hline $\begin{array}{l}\text { Rheumatism } \\
\text { Mental health }\end{array}$ & $1.396^{*}$ & 2. $292^{*}$ & ns & ns & ns & ns \\
\hline $\begin{array}{l}\text { Mental } \\
\text { problems }\end{array}$ & $1.578^{\star}$ & $5.806^{\star \star}$ & $5.149^{* *}$ & $1.506^{*} 1.506^{*}$ & $15.214^{* *}$ & $3.182^{\star *}$ \\
\hline $\begin{array}{l}\text { Health Risk Bel } \\
\text { (smoking) }\end{array}$ & ivior & $1.223^{\star \star}$ & $1.773^{* *}$ & Nsns & ns & ns \\
\hline
\end{tabular}

Physical abuse of the elderly is 2.5 times more likely in the case of asthma, 2.3 times more likely for rheumatism, and 5.8 times more likely for mental health problems. Physical injuries in elderly are 5.2 times more likely to be reported in cases where they suffer from mental health problems. Financial abuse of elderly is significant and is 1.7 times more likely in cases of stomach disease and 1.5 times more likely with mental health problems. Sexual abuse of elderly women in our study is 5.9 times more likely when the person has asthma and 15.2 times more likely with mental health problems. Neglect of elderly is significant and is 2.8 times more likely in the case of asthma, 1.8 times more likely with diabetes, and 3.2 times more likely with mental health problems.

Mental health problems are a risk factor for all types of abuse and neglect.

Mental health problems refer to self-reported subjective assessment about personal mental or emotional health. They are not been measured with psychological tests or scales. Mental or emotional health refers to overall psychological well-being. It includes feelings about us, the quality of relationships, and ability to manage feelings and deal with difficulties.

With regards to health risk behavior, only smoking was detected as a relevant risk factor for physical violence and physical injuries.

\section{Discussion}

As for the risk factors, many studies have been exploring the characteristics of different nature, the presence of which increases the probability of physical and emotional/psychological abuse, financial abuse and neglect. Most commonly the risk factors analyzed include: age, gender, living arrangement, acute or chronic health conditions, mental health status, cognitive functions, social support and usage of alcohol and cigarettes [7, 6, 18]. In the Macedonian study, with regards to the ecological framework, relevant risk factors on individual level identified were: education, gender, marital status, physical and mental health, sensory functioning (vision and hearing) and health risk behavior (smoking).

\section{Individual level risk factors}

Findings from recent studies indicate that lower level of education is a relevant risk factor of abuse/neglect [19]. In terms of education, Macedonian respondents with elementary education had a higher probability of being maltreated. However, it cannot be said that the decreasing of level of education is a risk factor, as we did not find differences among respondents with "no education", "incomplete education" and "higher education". Further research can provide more detailed explanation of this phenomenon.

Females had a higher probability to be maltreated in every type of abuse and neglect, except financial abuse. The findings simply followed the general tendency in violence toward females in Macedonia: one in two women in Macedonia is a victim of psychological abuse, every $6^{\text {th }}$ woman is victim of physical violence and every $10^{\text {th }}$ woman is a victim of sexual abuse [20]. Studies from other countries [18] also support this finding: women are almost twice as often victims of abuse $(63.2 \%)$ than men $(36.8 \%)$ [8]; elder women were about twice as likely than men to report verbal abuse but did not differ in the odds of reporting financial abuse [6] elder women experience sexual/physical assault almost three times more than men, congruent to the theoretical expectations and the findings of previous research [21].

Older married people showed greater likelihood of being abused compared to those who are widowed, singled or divorced. Research studies conducted in US indicated that at least one-sixth of all married couples experience one violent episode every year (FBI Law Enforcement Bulletin according to Gormly and Brodzinski, [22]). Pielmer and Finkelhor reported that in the USA spouses were found to be the most likely abusers and roughly equal numbers of men and women were victims [23].

Findings from different studies show that many chronic diseases, such as musculoskeletal, 
diabetes, physical disability, cardiovascular problems, digestive and excretory system [8], as well as general poor health [24] can be risk factors for elder Maltreatment. In the Macedonian study physical health, sensory impairment and health risk behavior were recognized as a relevant risk factor for various types of elder maltreatment.

\section{Mental health}

As many studies revealed victims of family abuse had poorer psychological health then those who had not been abused [25], poor mental competency [24] and cognitive impairment [18]. In this study self-reported mental health problems are a risk factor for all types of abuse and neglect.

The UK study [26] highlighted one very important risk factor for elderly abuse; consistently this emerges in relation to all types of maltreatment depression (although it is not clear what occurs first abuse, then depression or depression than abuse). The Macedonian study identifies that low level of depression is a relevant factor for elderly abuse. Respondents, who showed lower level of depression, reported some types of abuse/neglect more frequently than those who showed higher level of depression. Such findings can be interpreted by the level of self engagement of respondents on being affected by their experiences of abuse/neglect and how they communicate these experiences. Namely, in the initial phase of depression people are more alert towards negative experiences, such as abuse or neglect; they can recognize them and can also communicate these experiences better with their environment. On the contrary, higher levels of depression are marked with more intense isolation, detachment from their own experience and from the environment, which minimize the possibility for the elderly to communicate and convey information on what they have experienced, including abuse and neglect [27].

Being in need of care (as a result of physical or mental illness) often leads to a mutual dependency of family members. This circumstance often alters the entire family system and can lead to a change of habits that affects the family's entire life situation. In these circumstances parents undergo a loss of autonomy and both sides experience a change of roles [28].

The Macedonian study replicates many results and findings from various studies originating from different parts of the world, and confirms identified individual risk factors for elderly abuse and neglect. Such risk factors derive from all assumed levels and support the multidimensionality of the problem. As the main findings show that elderly maltreatment is an outcome of the interaction between the individual, relational, community-level and societal factors, and we should not even open debate about elder maltreatment prevention without taking into consideration all risk factors in an overall global picture. Isolating different risk factor can be misleading for the creative and constructive efforts in the process of prevention and management of the problems and issues concerning the elderly.

This study which attempted to identify possible risk factors on individual level for elderly maltreatment did not include older people suffering from a severe dementia and elderly who live in care homes or are hospitalized or imprisoned. The survey did not involve many other societal factors which might be relevant for elderly maltreatment (negative attitudes and stereotypes towards older people or cultural norms supportive of violence), financial/ dependence of the perpetrator).

\section{References}

1. World Health Organization. The Toronto Declaration on the Global Prevention of Elder Abuse. Geneva: WHO, 2002.

2. Krug EG, Dahlberg LL, Mercy JA, Zwi AB \& Lozano R eds. World report on violence and health. Geneva: World Health Organization, 2002.

3. Wu L, Chen H, Hu Y, Zhanh T, Cao Z. \& Wang Y. Prevalence and Associated Factors of Elder Mistreatment in a Rural Community in People's Republic of China: A Cross-Sectional Study. PLoS ONE. 2012; 7(3).e33857.

4. Ministry of Health, Republic of Macedonia. Report on violence and health in Macedonia and guide for prevention. Skopje: Author, 2006.

5. Ministry of Labour and Social Policy, Republic of Macedonia. Annual report 2010. Skopje: Author, 2010.

6. Bonie RJ, Wallace RB, eds. Elder Mistreatment. Abuse, Neglect and Exploitation in an Aging America. Washington DC: The national Academies Press, 2003

7. Bronfenbrenner U. Ecological model of human development. International Encyclopaedia of Education, Vol, 3, $2^{\text {nd }}$. Ed. Oxford, UK: Elsevier. Reprinted in Gauvain M, Cole M, eds. Readings on the development on children, $2^{\text {nd }}$ ed (37-43). NY: Freeman, 1993.

8. Marmolejo II. Elder abuse in the family in Spain. Valencia: The Queen Sofia Center Study, 2008.

9. Karolinska Institute. ABUEL, Abuse of elderly in Europe. Stockholm: Karolinska Institute, 2009.

10. National Institute for Health and Welfare THL. Prevalence study of violence and abuse against older women (AVOW). Helsinki: National Institute for Health and Welfare THL, 2010.

11. Sheik JI, Yesavage JA. Geriatric Depression Scale (GDS): recent evidence and development of shorter version. Clinical gerontology: a guide to assessment and intervention. New York: Haworth Press, 1986.

12. Raspopovic ED. Geriatric Depression Scale. Belgrade: Clinical Center of Serbia, Clinics for Physical Medicine and Rehabilitation, 2011.

13. State Statistical Office, Republic of Macedonia. Macedonia in figures. Skopje: State Statistical Office, Republic of Macedonia, 2010.

14. Krsteska R. Mini Mental Test kaj Alchajmerova i vaskularna demencija. [Mini Mental Test in Alzheimer's and vascular dementia.]. Makedonski Medicinski Pregled [Macedonian Medical Review]. Skopje: University "Ss Cyril and Methodius", 2007. 
15. Kurlowicz L, Wallace M. Mini -Mental State Examination (MMSE). New York: Hartford Institute for Geriatric Nursing, 1999.

16. Alzheimer's Society. The Mini Mental State Examination (MMSE). London: Alzheimer's Society, 2012.

17. Namkee GC, Mayer J. Elder abuse, neglect and exploitation: risk factors and prevention strategies. Journal of Gerontological Social Work, 2000; 33:2.

18. Barker NN, Himchak MV. Environmental issues affecting elder abuse victims in their reception of community based services. Journal of Gerontological Social Work. 2006; 48(12):233-255.

19. Sethi D, Wood S, Mitis F, et al., eds. European report on preventing elder maltreatment. Copenhagen: WHO Regional Office for Europe; 2011.

20. Здружение за еманципација, солидарност и еднаквост на жените на PM - ECE [Association for Emancipation, Solidarity and Equality of Women in the Republic of Macedonia]. Животот во сенка [Life in shadow]. Skopje: ESE, 2006.

21. Brozowski K, Hall DR. Aging and risk: Physical and Sexual Abuse of Elders in Canada. Journal of Interpersonal Violence, 2010.

22. Gormly A, Brodzinski D. Lifespan human development. San Diego, California: Harcourt Brace College, 1990.

23. Pillemer K, Finkelhor D. The Prevalence of Elder Abuse: A Random Sample Survey. The Gerontologist. 1988; 28: 51-57.

24. Peri K, Fanslow J, Hand J, Parson J. Elder abuse and neglect exploration of risk and protective factors. Wellington: Families Commission, 2004.

25. Ajdukovic M, Rusac S, Ogresta J. Izlozenost starijih osoba nasilju u obitelji [Exposure of elderly to family violence]. Revija za socijalnu politiku [Journal of Social Policy]. 2008; 15(1):322.

26. O'Keeffe M, Hills A, Doyle M, et al. The UK study of abuse and neglect of older people. Prevalence study. London: National centre for social research, King's College, 2007.

27. The Royal Australian College of General Practitioners. Medical care of older persons in residential aged care facilities (silver book). East Melbourne: Author, 2012.

28. Cardoso JC, Segal UA. Family violence and elder abuse-an insight on concept and practices for caregivers. Porto: Revista de Faculdade de Ciencias da Saude Porto Edicoes Universidade Fernando Pessoa, 2009. 